\title{
Mechanisms for transmission of infectious salmon anaemia (ISA)
}

\author{
A. Nylund, T. Hovland, K. Hodneland, F. Nilsen, P. Løvik \\ Department of Fisheries and Marine Biology, HiB, University of Bergen, N-5020 Bergen, Norway
}

\begin{abstract}
Atlantic salmon exposed to organic material (like blood) containing the infectious salmon anaemia (ISA) agent, or to salmon lice from ISA-infected fish, suffered high mortalities. Coprophagy was observed and may be of importance when the disease has reached a fish farm, i.e. during an outbreak. It is suggested that salmon lice may be an important vector for the ISA agent in epidemic and endemic phase. Although passive transmission in seawater may be of lesser importance in the spread of the agent, it was demonstrated in this study that the ISA agent was still infectious after $20 \mathrm{~h}$ in seawater and $4 \mathrm{~d}$ in blood and kidney tissue kept at $6^{\circ} \mathrm{C}$.
\end{abstract}

KEY WORDS: Infectious salmon anaemia $\cdot$ Epizootiology $\cdot$ Salmon lice

\section{INTRODUCTION}

In order to control diseases it is crucial to know the mechanisms for spreading. One of the most important diseases in Norwegian fish farms is infectious salmon anaemia (ISA). ISA is a viral disease of farmed Atlantic salmon Salmo salar L. in Norway, and was recorded for the first time in late autumn 1984 (Thorud \& Djupvik 1988). It has only been diagnosed in Atlantic salmon after the fish have been transferred to sea or when salmon have been exposed to seawater in hatcheries. ISA is characterized by severe anaemia and high mortalities. Other symptoms exhibited are exophthalmia, ascites, congestion and enlargement of the liver and spleen, congestion in the intestinal mucosa, and usually petechiae in the visceral fat (Evensen et al. 1991, Thorud 1991, Nylund et al. 1993). The disease can be transmitted using homogenates of tissue obtained from diseased fish. Virus particles with a morphology similar to the Arenaviridae have been found in Atlantic salmon suffering from ISA (Hovland et al. in press, Nylund et al. unpubl.). These particles are believed to be the causative agent of the disease, but it has not yet been possible to culture the virus.

The epizootiology of ISA was described by Vågsholm et al. (1993). They described risk factors that may aid the spread of ISA in the epidemic and endemic phase and gave a list of measures that could possibly prevent the spread of the disease. They also suggested that the most important mechanism for the spread of the agent from a reservoir to new hosts is passive transmission in seawater. However, in spring 1992 Nylund et al. (1993) showed that the salmon lice could function as a vector for ISA. In the epidemiological phase, sea lice (Caligus elongatus and Lepeophtheirus salmonis) on salmon with ISA could represent an important vector in the spread of the disease from one fish farm to another. It has been shown by K. Birkeland (cf. Jakobsen 1993) that preadult and adult stages of $L$. salmonis move from host to host, and it has been observed that well-fed adults of C. elongatus may leave the host and live in plankton, later to attack other fish (Kaestner 1970). Ectoparasites as vectors of viral and bacterial diseases of fish have been discussed by Horne (1928), Ahne (1985), Cusack \& Cone (1985, 1986), Cusack et al. (1988), Mulcahy et al. (1990), and Nylund et al. (1991, 1992, 1993).

It is crucial for the management of this disease in Norway, and for the prevention of spread to fish farms in other countries, that the mechanisms of transmission from reservoirs to new hosts are determined. The transfer of disease from affected fish to healthy fish can occur via the skin (mucous membrane, abrasions, etc.), urine, and feces. Hence, the aim of the present study was to examine the following potential transfer mechanisms: vector transmission by sea lice, transmission in organic material and passive transmission (in seawater). 


\section{MATERIALS AND METHODS}

All Atlantic salmon Salmo salar used in this experiment were supplied by EWOS, Lønningdal, Norway. The hatchery had no history of disease. The mean weight and length of the smolts when taken into the laboratory were $44 \mathrm{~g}$ and $15.5 \mathrm{~cm}$. The smolts were transferred to seawater ( $34 \%$ ) after arrival at the laboratory and kept in $0.15 \mathrm{~m}^{3}$ tanks, about 50 specimens in each, at water temperatures from 8 to $12^{\circ} \mathrm{C}$.

The blood (heparinized and stored at $-80^{\circ} \mathrm{C}$ ) used in these experiments, with the exception of tasks $\mathrm{D}$ and $E$ (see below), was of the same origin (collected from Atlantic salmon during a natural outbreak of ISA in a fish farm near Bergen, Norway). The disease was diagnosed by local veterinarians. Preparation of the filtrate used in the experimental challenges was as follows: the heparinized blood was cold centrifuged at $2000 \mathrm{rpm}(913 \times \mathrm{g})$ for $10 \mathrm{~min}$ to separate the blood cells from the plasma. The blood cells were diluted with Earle's Balanced Salt Solution (EBSS) 1:1 and sonicated in an Ultra-Turrax 25 for $10 \mathrm{~s}$. The solution was then cold centrifuged at $3700 \mathrm{rpm}(3200 \times \mathrm{g})$ for $10 \mathrm{~min}$. The supernatant and the blood plasma were passed through a $0.2 \mu \mathrm{m}$ pore sterile filter, mixed and kept on ice prior to challenge.

Experimental groups (Table 1). Task A: ISA-infected blood was sonicated and $100 \mathrm{ml}$ were added to a $30 \mathrm{l}$ tank containing seawater and smolts (group BSA). The

Table 1. Experimental groups in this study. The groups are named as follows: the first letter describes treatment (B: bath; C: cohabitation with infected individuals ${ }_{i} I_{\text {: intraperitoneal }}$ injection), the middle letter indicates the type of tissue used in the challenge and how this tissue was treated (E: Earle's Balanced Salt Solution; F: sonicated and filtered ISA-blood; H: Hanks' Balanced Salt Solution; K: sonicated and filtered tissue from the kidney; L: cohabitant with ISA and salmon lice; O: cohabitant with ISA; S: sonicated blood; V: lice present on fish challenged with sonicated and filtered ISA-blood; W: filtered seawater from wellboat tank), and the last letter shows the task $\{A, B, C, D, E\}$. The control groups are given the first 2 letters only (with the exception of the control group in task E)

\begin{tabular}{|cclccc|}
\hline Group & $\mathrm{N}$ & Dose & Group & $\mathrm{N}$ & Dose \\
\hline Task A & & & Task D & & \\
IFA & 44 & $0.2 \mathrm{ml}$ & IKD & 44 & $0.2 \mathrm{ml}$ \\
BFA & 46 & $1: 300$ & IWD & 48 & $0.2 \mathrm{ml}$ \\
BSA & 47 & $1: 300$ & IFD & 47 & $0.2 \mathrm{ml}$ \\
Task B & & & Control & & \\
BFB & 46 & $1: 300$ & IE & 39 & $0.2 \mathrm{ml}$ \\
IFB & 45 & $0.2 \mathrm{ml}$ & BE & 32 & $1: 300$ \\
BVB & 33 & $1: 300$ & Task E & & \\
Task C & & & IKE & 60 & $0.2 \mathrm{ml}$ \\
CLC & 38 & 5 cohabitants & IFE & 40 & $0.2 \mathrm{ml}$ \\
COC & 39 & 5 cohabitants & IHE & 30 & $0.2 \mathrm{ml}$ \\
& & & & & \\
\hline
\end{tabular}

salmon were challenged for $1 \mathrm{~h}$ before the seawater was allowed to circulate. The remainder of the blood was filtered through a $0.2 \mu \mathrm{m}$ pore filter. The second group (BFA) of salmon were bathed in $100 \mathrm{ml}$ of the filtrate diluted in $30 \mathrm{l}$ of seawater for $1 \mathrm{~h}$. In the third group (IFA), $0.2 \mathrm{ml}$ of the filtrate was injected intraperitoneally (i.p.) into each specimen.

Task B: ISA-blood was sonicated and filtered and used to challenge 3 groups. Two groups (BFB and BVB) were each bathed in $100 \mathrm{ml}$ of the filtrate diluted in $30 \mathrm{I}$ of seawater for $1 \mathrm{~h}$. Each group was kept in a separate tank. The smolts in group BVB were infected with 5 to 10 preadult salmon lice each, while no lice were present on the smolts in group BFB. In the third group (IFB) $0.2 \mathrm{ml}$ of the filtrate was injected i.p. into cach specimen. After $38 \mathrm{~d}$ groups BFB and BVB were anaesthetised with Benzocaine and injected i.p. with $0.2 \mathrm{ml}$ prednisoloneacetate $\left(10 \mathrm{mg} \mathrm{m}^{-1}\right)$. The temperature was raised to $16^{\circ} \mathrm{C}$ and the fish were kept at this temperature for $25 \mathrm{~d}$.

Task C: Five specimens of Salmo salar with signs of ISA were added to each of 2 groups; one with 5 to 10 preadult salmon lice on each individual (group CLC) and the other without any lice in the tank (group COC). The 5 specimens added to group CLC were also infected with 5 to 10 preadult salmon lice, while the 5 specimens added to group COC were without lice. The salmon lice used in these experiments were cultured in our laboratory and the copepodites were used to infect the smolts. When the lice reached the second preadult stage the smolts were used for the experiments. Each fish was infected by 5 to 10 preadult lice.

Task $D$ : Six tons of Atlantic salmon suffering from ISA were kept in a $74 \mathrm{~m}^{3}$ tank for $5 \mathrm{~h}$. Thirty-two specimens were collected at random, signs of disease were registered and blood and kidney samples were taken. Ten of these individuals showed typical signs of ISA and skin lesions were also present. The mean hematocrit for the 32 specimens was 37 , range 10 to 54 . Blood and kidney from 6 of these specimens (mean hematocrit 16, range 10 to 21 ) were used to challenge 2 groups of Atlantic salmon, IFD and IKD. The blood and kidney tissues were kept separate, sonicated, filtered (0.2 $\mu \mathrm{m}$ pore diameter), and $0.2 \mathrm{ml}$ was injected i.p. into the smolts in these 2 groups. Another group (IWD) was challenged i.p. with filtered seawater from the wellboat tank, $0.2 \mathrm{ml}$ injected per salmon.

Controls for tasks $A$ to $D$ : Two control groups of smolts were used. In one group (IE) $0.2 \mathrm{ml}$ of EBSS was injected i.p. while the other control group (BE) was bathed in $100 \mathrm{ml}$ of EBSS in 301 of seawater for $1 \mathrm{~h}$.

Task E: To learn more about the length of survival of the ISA virus in blood and tissue, blood and kidney tissue were collected from salmon during a natural outbreak of ISA (in a fish farm in northern Norway). 
These samples were transpor:ed to our laboratory in Bergen (i.e. kept at $20^{\circ} \mathrm{C}$ for $8 \mathrm{~h}$ ) and, on arrival, stored at $6^{\circ} \mathrm{C}$ for $96 \mathrm{~h}$ before they were used to challenge disease-free salmon. Just before challenge, the blood and kidney tissue (kept separately) were sonicated, filtered $(0.2 \mu \mathrm{m})$, and diluted 1:1 with Hanks' Balanced Salt Solution (HBSS). One group of salmon (IKE) received an i.p. injection of $0.2 \mathrm{ml}$ of the kidney filtrate and another group (IFE) an i.p. injection of $0.2 \mathrm{ml}$ of the blood filtrate. The control group (IHE) received an i.p. injection of $0.2 \mathrm{ml} \mathrm{HBSS}$. The groups were kept in separate tanks $\left(0.15 \mathrm{~m}^{3}\right)$ at $12^{\circ} \mathrm{C}$ with running seawater.

Survival of the ISA agent in salt water. ISA-blood was sonicated, filtered and diluted 1:1 with seawater ( $34 \%$ ) or EBSS. The 2 solutions were injected i.p. into smolts according to the following time schedule: $10 \mathrm{~min}, 2.5 \mathrm{~h}$ and $20 \mathrm{~h}$ after preparation of the solutions. The smolts were individually tagged and kept in the same tank. The 2 solutions were stored at $6^{\circ} \mathrm{C}$. A control group of 13 smolts was also kept in the same tank and received an i.p. injection of $0.2 \mathrm{ml}$ EBSS.

In addition, weight and length were measured, haematocrits determined, clinical signs of disease registered, and tissues for histological examination were taken. Each fish was also examined bacteriologically by inoculation of kidney tissue onto blood agar plates, which were incubated at $20^{\circ} \mathrm{C}$ for $6 \mathrm{~d}$, and on blood agar plates containing $2 \% \mathrm{NaCl}$ which were incubated for 6 d at $15^{\circ} \mathrm{C}$.

\section{RESULTS}

The number of mortalities in each group after 30 and $70 \mathrm{~d}$, and mean haematocrit values for the survivors, are given in Table 2. In each group the mortality occurred in 2 separate periods, one from about Day 17 until Day 30, and the other starting at about Day 35.

The i.p. injection of sonicated and filtered ISA-blood into salmon smolts resulted in the following mortalities during the first $30 \mathrm{~d}$ : 6,45 and $82 \%$ for groups IFD, IFA and IFB respectively. After $70 \mathrm{~d}$ the mortalities were $45 \%$ (IFD), $59 \%$ (IFA) and 100\% (IFB). The specimens that died in groups IFA, IFB and IFD showed all the clinical signs of ISA, and no bacteria were isolated from the kidney. The lowest haematocrit value registered was 1 (range 1 to 20 ).

Two specimens died in the group (IWD) challenged by i.p. injection of filtered sea- water from the wellboat. One specimen died after $30 \mathrm{~d}$ in the control group (IE) injected with EBSS. Bacteria were isolated from the kidney of the control fish and the 2 fish from group IWD, and no signs of ISA were present in these individuals. The bacteria isolated were not identified as a species that commonly infects salmon in Norwegian fish farms.

In the last group in the wellboat study (task D) mortality after $30 \mathrm{~d}$ was IKD: $18 \%$; after $70 \mathrm{~d}$ the mortalities in the wellboat study were IKD: $84 \%$, IFD: $45 \%$ and IWD: $4 \%$. The specimens that died in groups IKD and IFD showed all the signs of ISA, and no bacteria were isolated from the kidney.

For smolts challenged by bath in a solution of sonicated and filtered ISA-blood diluted in seawater $(1: 300)$ mortalities after $30 \mathrm{~d}$ were BFA: $0.0 \%$, BFB: $6 \%$ (3 specimens) and BVB: $6 \%$ (2 specimens). The 2 specimens from group $B V B$ and 1 specimen from group BFB showed clinical signs of ISA. Bacteria were not isolated from these 3 specimens. However, bacteria were isolated from the other specimens that died in group BFB and BVB. These bacteria were not among the known fish pathogens in Norwegian fish farming. One individual died in each group (BFB and BVB)

Table 2. Results of different experimental challenges of salmon smolts with the ISA agent. N: no. of specimens in each group; mortalities: no and $\%$ of specimens that died in each group during the experiment haematocrit: mean and range of haematocrit of survivors

\begin{tabular}{|c|c|c|c|c|c|c|c|}
\hline \multirow[t]{3}{*}{ Group } & \multirow[t]{3}{*}{$\mathrm{N}$} & \multicolumn{4}{|c|}{ Mortalities } & \multicolumn{2}{|c|}{ Hematocrit } \\
\hline & & \multicolumn{2}{|c|}{$30 \mathrm{~d}$} & \multicolumn{2}{|c|}{$70 \mathrm{~d}$} & \multirow[t]{2}{*}{ Mean } & \multirow[t]{2}{*}{ Range } \\
\hline & & no. & $\%$ & no. & $\%$ & & \\
\hline \multicolumn{8}{|l|}{ Task A } \\
\hline IFA & 44 & 20 & 45 & 26 & 59 & 45.1 & $31-63$ \\
\hline$B F A$ & 46 & 0 & 0 & 0 & 0 & 56.6 & $43-65$ \\
\hline $\mathrm{BSA}$ & 47 & 15 & 32 & 17 & 36 & 42.4 & $25-56$ \\
\hline \multicolumn{8}{|l|}{ Task B } \\
\hline$B F B$ & 46 & 3 & 6 & 4 & 9 & 50.7 & $32-69$ \\
\hline IFB & 45 & 37 & 82 & 45 & 100 & - & - \\
\hline $\mathrm{BVB}^{\mathrm{a}}$ & 33 & 2 & 6 & 3 & 9 & 43.9 & $27-58$ \\
\hline \multicolumn{8}{|l|}{ Task C } \\
\hline $\mathrm{CLC}^{\circ}$ & 38 & 26 & 68 & 38 & 100 & - & - \\
\hline $\mathrm{COC}$ & 39 & 6 & 15 & 23 & 58 & 42 & $20-55$ \\
\hline \multicolumn{8}{|l|}{ Task D } \\
\hline IKD & 44 & 8 & 18 & 37 & 84 & 37.8 & $23-47$ \\
\hline IWD & 48 & 2 & 4 & 2 & 4 & 45.7 & $33-60$ \\
\hline IFD & 47 & 3 & 6 & 21 & 45 & 42.3 & $19-55$ \\
\hline \multicolumn{8}{|l|}{ Control } \\
\hline IE & 39 & 1 & 2 & 3 & 8 & 48.8 & $33-61$ \\
\hline $\mathrm{BE}$ & 32 & 0 & 0 & 1 & 3 & 47.9 & $30-60$ \\
\hline \multicolumn{8}{|l|}{ Task E } \\
\hline IKE & 60 & 2 & 3 & - & - & - & - \\
\hline IFE & 40 & 7 & 18 & - & - & - & - \\
\hline IHE & 30 & 0 & 0 & - & - & - & - \\
\hline
\end{tabular}


during the latent carrier test (LCT). These 2 specimens showed some of the signs of ISA. The salmon lice in group BVB had been feeding on the hosts according to the contents in the gut of the lice, and haemorrhaging and complete erosion of the host epidermis at the points of feeding.

The group challenged by bath in sonicated ISA-blood diluted in seawater $(1: 300)$ showed a mortality of $32 \%$ (group BSA) during the first $30 \mathrm{~d}$. The specimens that died in group BSA showed all the clinical signs of ISA.

One specimen died in the control group (BE) bathed in EBSS. Bacteria were isolated from the kidney of the control fish and no signs of ISA were present. The bacteria isolated were not among the known fish pathogens in Norwegian fish farming.

The 5 cohabitants with ISA in group CLC died on the following days after challenge, Day 1: 2 specimens, Day 2: 1 specimen, Day 6: 2 specimens. In group COC the cohabitants with ISA died on Day 1 (1 specimen), Day 2 (2 specimens), Day 19 (1 specimen) and Day 22 (1 specimen). The cohabitants in the 2 groups showed all signs of ISA and the bacterial samples from the kidney were negative. In the fish challenged in the 2 groups mortalities after $30 \mathrm{~d}$ were CLC: $68 \%$ and COC: $15 \%$. The specimens that died in groups CLC and COC showed all signs of ISA, and no bacteria were isolated from the kidney. The number of salmon lice on the smolts in group CLC declined towards the end of the experiment. In the last $10 \mathrm{~d}$ the mean intensity was 1 . Coprophagy were observed in both groups, i.e. the smolt were observed to eat feces containing blood from the cohabitants suffering from ISA.

The mortalities in group IFE started $17 \mathrm{~d}$ after challenge and $18 \%$ of the fish died before Day 30 . In the group challenged with kidney tissue (IKE) only $3 \%$ died before Day 30. The fish that died showed all the typical signs of ISA and the virus was present in the different tissues. There were no mortalities in the control group (IHE)

The results of the study of survival of the ISA agent in salt water are given in Table 3. All the fish challenged by injection of the ISA agent diluted in seawater or EBSS died before mortalities began in the control group. The fish showed all signs of ISA and no bacteria were isolated from the kidney samples. The smolts were observed to eat feces containing blood from the cohabitants suffering from ISA.

\section{DISCUSSION}

It has been shown that sea lice Lepeophtheirus salmonis can function as a vector for the ISA agent (Nylund et al. 1993). This study has also shown that challenge of salmon smolts by i.p. injection of soni-
Table 3. Survival of the ISA agent in salt water. Sonicated/ sterile filtered blood from ISA-infected salmon was diluted 1:1 in seawater ( $34 \%$ ) or EBSS respectively. The 2 solutions were injected intraperitoneally into smolts $(0.2 \mathrm{ml}$ each) $10 \mathrm{~min}$ (I), $2 \mathrm{~h}$ (II) and $20 \mathrm{~h}$ (III) after their preparation. Control fish were injected with EBSS only. Days: no. of days fish survived after injection; ISA: signs of disease present $(+)$ or absent (-)

\begin{tabular}{|c|c|c|c|}
\hline Solution & Days & $N$ & ISA \\
\hline EBSS-I & $\begin{array}{l}18 \\
19 \\
20\end{array}$ & $\begin{array}{l}3 \\
1 \\
1\end{array}$ & $\begin{array}{l}+ \\
+ \\
+\end{array}$ \\
\hline Sea-I & $\begin{array}{l}21 \\
22 \\
24\end{array}$ & $\begin{array}{l}2 \\
1 \\
2\end{array}$ & $\begin{array}{l}+ \\
+ \\
+\end{array}$ \\
\hline EBSS-II & $\begin{array}{l}20 \\
21 \\
22\end{array}$ & $\begin{array}{l}1 \\
2 \\
2\end{array}$ & $\begin{array}{l}+ \\
+ \\
+\end{array}$ \\
\hline Sea-II & $\begin{array}{l}19 \\
21 \\
24\end{array}$ & $\begin{array}{l}2 \\
2 \\
1\end{array}$ & $\begin{array}{l}+ \\
+ \\
+\end{array}$ \\
\hline EBSS-III & $\begin{array}{l}23 \\
24 \\
26 \\
27\end{array}$ & $\begin{array}{l}1 \\
2 \\
1 \\
1\end{array}$ & $\begin{array}{l}+ \\
+ \\
+ \\
+\end{array}$ \\
\hline Sea-III & $\begin{array}{l}20 \\
21 \\
24\end{array}$ & $\begin{array}{l}1 \\
3 \\
1\end{array}$ & $\begin{array}{l}+ \\
+ \\
+\end{array}$ \\
\hline Control & $\begin{array}{l}28 \\
30 \\
31 \\
32 \\
35 \\
37 \\
42\end{array}$ & $\begin{array}{l}1 \\
1 \\
1 \\
2 \\
6 \\
1 \\
1\end{array}$ & $\begin{array}{l}+ \\
+ \\
+ \\
+ \\
+ \\
+ \\
-\end{array}$ \\
\hline
\end{tabular}

cated filtered ISA-blood results in the same mortality as experimental challenge with salmon lice from ISA infected fish. Hence, due to the difficulties of obtaining and working with salmon lice from fish with ISA, i.p. injections may be used as an indicator of exposure of salmon to ISA-infected lice.

The importance of sea lice compared to other transmission mechanisms is not known. The present study indicates that transmission of free ISA agent passively through seawater does occur. However, smolts challenged by bath in seawater containing the ISA agent (groups BFA, BFB and BVB) did not result in significant mortalities or signs of ISA. Nor did injection of filtered seawater (group IWD) from the wellboat tank containing salmon with ISA. But when organic material was present (sonicated bloodcells, group BSA) the bath-challenged smolts developed ISA and $32 \%$ died during the first $30 \mathrm{~d}$. One explanation for this could be that virus particles are lost during preparation of the filtrate and that the virus titre was too low to produce an infection. However, it is not reasonable to believe that the concentration of virus in a net pen will 
be higher than the dose used in these experiments or that in the seawater from the wellboat tank, but the duration of the challenge will last longer in a net pen. Another explanation could be that organic material enhances the uptake of the virus. Such an explanation would support the view that blood from fish processing plants may have been important in the spread of the disease (Vågsholm et al. 1993)

The presence of salmon lice on the fish bathed in ISA/seawater (group BVB) did not increase the possibility of an ISA infection. The lice on the fish had been feeding, judging from the gut contents of the lice and the presence of haemorrhages in the host skin, indicating that the protection of the integument had been weakened. This suggests that the most important infection route of the ISA agent may not be through lesions in the integument, i.e. secondary infections due to integumentary wounds caused by salmon lice.

Challenge by cohabitants (groups CLC and COC) shows that the ISA agent can be transmitted from one host to the next without the presence of sea lice. Again, this could be due to passive transmission of the agent through seawater. However, coprophagy were observed in both groups (CLC and COC) and it is likely that the level of virus in the feces from ISA-infected salmons constitutes a higher challenge compared to virus in seawater. Still, coprophagy only seems to have an additional effect since the mortality in group CLC (where sea lice were present) was $68 \%$ while the mortality in group COC was $15 \%$ after $30 \mathrm{~d}$. Previous experiments have shown that the lice move from host to host in the tanks (pers. obs.) and this also occurs in nature (cf. Kaestner 1970, Jakobsen 1993). This suggest that the salmon lice do have a potential as a vector for the ISA virus as shown by Nylund et al. (1993).

The survival test showed that the ISA agent can survive in seawater for at least $20 \mathrm{~h}$ at $6^{\circ} \mathrm{C}$ and for $4 \mathrm{~d}$ in tissue (groups IFE and IKE) at $6{ }^{\circ} \mathrm{C}$. This fact has important implications for the spread and maintenance of the disease. During epizootics, sea lice on salmon with ISA may be very important for the spread of the disease from one fish farm to another. Passive transmission of the agent through seawater would probably be negligible with respect to spread of the disease due to the dilution effect, even if the agent is still infective after several hours in seawater. The number of virus particles meters away from a net pen with salmon suffering from ISA will certainly be lower compared to the bath challenge in this study.

The distance of spread of the virus by blood and feces from ISA infected fish, compared to the spread by sea lice on infected salmon, is probably very limited. The importance of algae and zooplankton as an organic substrate for the spread of the agent has not been studied, and cannot be excluded from the epi- zootiology of ISA (Ahne 1985, Cusack \& Cone 1985 1986, Cusack et al. 1988, Mulcahy et al. 1990, Nylund et al. 1991, 1992, 1993). In the endemic phase of the disease, sea lice, coprophagy and passive transmission may all be important. Other possible mechanisms for spread of ISA have been discussed by Vågsholm et al. (1993).

Future studies on the epizootiology of ISA should concentrate upon the survival time of the agent in seawater, sea lice, plankton and organic material. The possibility that wild fish species, e.g. sea trout, serve as carriers for the ISA agent should also be investigated. Today we also lack knowledge concerning the possibility of ISA being present in stored fish destined for market. However, the ISA virus has been found in somatic muscle of infected salmon (Hovland et al. in press, Nylund et al. unpubl.), and as shown in task $E$ the virus is still present in blood and kidney tissue as late as $4 \mathrm{~d}$ after the fish has been killed. The virus is still infective even if the low mortalities in the challenged fish (group IKE and IFE) indicates a low virus titre at this time. Hence, a major concern is the possibility of spread of the ISA virus via the export of salmon from areas and fish farms where ISA is known to occur. Knowledge about this aspect of ISA is of crucial importance for all countries farming Atlantic salmon and for salmon farmers in those areas in Norway where ISA does not occur.

Acknowledgement. We are greatly indebted to EWOS for kindly supplying the salmon smolts used in this work.

\section{LITERATURE CITED}

Ahne, W. (1985). Argulus foliaceus L. and Piscicola geometra L. as mechanical vectors of spring viraemia of carp virus (SVCV). J. Fish Dis. 8: 241-242

Cusack, R., Cone, D. K. (1985). A report of bacterial microcolonies on the surface of Gyrodactylus (Monogenea) J. Fish Dis. 8: 125-127

Cusack, R., Cone, D. K. (1986). A review of parasites as vectors of viral and bacterial diseases of fish. J. Fish Dis. 9 169-171

Cusack, R., Rand, T., Cone, D. K. (1988). A study of bacterial microcolonies associated with the body surface of Gyrodactylus colemanensis Mizelle \& Kritsky, 1967 (Monogenea), parasitizing Salmo gairdneri Richardson. J. Fish Dis. 11: 271-274

Evensen, Ø., Thorud, K. E., Olsen, Y. A. (1991). A morphological study of the gross and light microscopic lesions of infectious anaemia in Atlantic salmon (Salmo salar). Res vet. Sci. 51:215-222

Horne, J. H. (1928). Furunculosis in trout and the importance of carriers in the spread of the disease. J. Hygiene Cambridge 28: $67-78$

Hovland, T., Nylund, A., Watanabe, K., Endresen, C. (in press). Observation of infectious salmon anaemia virus (ISAV) in Atlantic salmon, Salmo salar L. J. Fish Dis.

Jakobsen. P. (1993). Lice infestation of wild salmonid populations in Norway. In: Meldon, J. (ed.) Aquaculture in 
Ireland - towards sustainability. An Taisce Publication, Dublin, p. 75-76

Kaestner, A. (1970). Invertebrate zoology. Crustacea, Vol. III. Interscience Publishers, New York

Mulchay, D., Klaybor, D., Batts, W. N. (1990). Isolation of infectious hematopoietic necrosis from a leech (Piscicola salmositica) and a copepod (Salmincola sp.), ectoparasites of sockeye salmon Oncorhynchus nerka. Dis. aquat. Org. 8: $29-34$

Nylund, A., Bjørknes, B., Wallace, C. (1991). Lepeophtheirus salmonis - a possible vector in the spread of diseases on salmonids. Bull. Eur. Ass. Fish Pathol. 11: 213-216

Nylund, A., Dkland, S., Bjørknes, B. (1992). Anatomy and ultrastructure of the alimentary canal in Lepeophtheirus salmonis (Copepoda; Siphonostomatoida). J. crust. Biol. 3: $423-437$

Responsible Subject Editor: F. M. Hetrick, College Park, Maryland, USA
Nylund, A., Wallace, C., Hovland, T (1993). The possible role of Lepeophtheirus salmonis (Kroyer) in the transmission of infectious salmon anaemia. In: Boxshall, G., Defaye, D (eds.) Pathogens of wild and farmed fish: sea lice, Vol. 28 Ellis Horwood Ltd, London, p. 367-373

Thorud, K. (1991). Infectious salmon anaemia. Transmission trials, haematological, clinical chemical and morphological investigations. Ph.D. theses, Norwegian College of Veterinary Medicine, Oslo

Thorud, K., Djupvik, H. O. (1988). Infectious anaemia in Atlantic salmon (Salmo salar L.). Bull. Eur. Ass. Fish Pathol. 8: 109-111

Vågsholm, I., Djupvik, H. O., Willumsen, F. V., Tveit, A. M. Tangen, K. (1993). Epidemiology of infectious salmon anaemia (ISA). Norsk Veterinærtidsskrift 105: 5-17 (in Norwegian)

Manuscript first received: May 30, 1993

Revised version accepted: March 7, 1994 